Article

\title{
Trends in Temperature and Rainfall Extremes near the Artificial Sobradinho Lake, Brazil
}

\author{
Maria Monalisa Mayara Silva Melo ${ }^{1}$, Carlos Antonio Costa dos $\operatorname{Santos}^{1}$ (iD, \\ Ricardo Alves de Olinda ${ }^{2}$, Madson Tavares Silva ${ }^{1}$, Raphael Abrahão ${ }^{3}$, Osias Ruiz-Alvarez ${ }^{4}$ \\ ${ }^{1}$ Unidade Acadêmica de Ciências Atmosféricas, Universidade Federal de Campina Grande, \\ Campina Grande, PB, Brazil. \\ ${ }^{2}$ Departamento de Estatística, Universidade Estadual da Paraiba, Campina Grande, PB, Brazil. \\ ${ }^{3}$ Centro de Energias Alternativas e Renováveis, Universidade Federal da Paraíba, \\ João Pessoa, PB, Brazil. \\ ${ }^{4}$ Water Management and Hydrological Science, Texas A\&M University, College Station, USA.
}

Received in November 29, 2017 - Accepted in June 5, 2018

\begin{abstract}
The formation of artificial lake due construction of a hydroelectric plant causes irreversible environmental impacts. Studies associated with these artificial lakes for the Brazilian semiarid region are still insufficient. Thus, the objective of this study is to provide new information on the trends of climatic extremes, dependent on rainfall and air temperature, for the Sobradinho Hydroelectric Power Plant (SHPP) lake region, through the analysis of climate change indices. This study is particularly important for the SHPP region because microclimate changes have significant impacts on the natural, social and economic sectors. For the two analyzed stations (Bebedouro-PE and Mandacaru-BA), it is not possible to affirm that the construction of the SHPP artificial lake altered the local microclimate. Trends of increase in maximum temperature, the number of hot days and diurnal temperature range were noticed. However, the rise of these indices cannot be attributed to the formation of the SHPP lake. The influence of the SST of Tropical Oceans on the temporal behavior of some of the indices used in this study may have contributed to increases in hot days and nights, maximum temperature, diurnal temperature range and consecutive dry days over the region.
\end{abstract}

Keywords: climate change, temperature, precipitation, hydroelectric power plant.

\section{Tendências de Extremos de Temperatura e Precipitação nas Proximidades do Lago Artificial de Sobradinho, Brasil}

\begin{abstract}
Resumo
A formação de lago artificial devido à construção de uma usina hidrelétrica causa impactos ambientais irreversíveis. Estudos associados a esses lagos artificiais para o semiárido brasileiro ainda são insuficientes. Assim, o objetivo deste estudo é fornecer novas informações sobre as tendências dos extremos climáticos, dependentes de temperatura do ar e precipitação, para a região do lago da Usina Hidrelétrica de Sobradinho (UHS), através da análise dos índices de mudanças climáticas. Este estudo é particularmente importante para a região da UHS, pois as mudanças no microclima têm impactos significativos nos setores natural, social e econômico. Para as duas estações analisadas (Bebedouro-PE e Mandacaru-BA), não foi possível afirmar que a construção do lago artificial da UHS alterou o microclima local. Tendências de aumento na temperatura máxima, quantidade de dias quentes e amplitude térmica diária foram observadas. No entanto, o aumento desses índices não pode ser atribuído à formação do lago da UHS. A influência da TSM dos Oceanos Tropicais no comportamento temporal de alguns dos índices utilizados neste estudo pode ter contribuído para o aumento nos dias e noites quentes, temperatura máxima, amplitude térmica diária e dias secos consecutivos na região.
\end{abstract}

Palavras-chave: mudança climática, temperatura, precipitação, usina hidrelétrica.

Corresponding author: Carlos Antonio Costa dos Santos, carlos.santos@ufcg.edu.br. 


\section{Introduction}

Most of the electricity in Brazil is generated in hydroelectric plants, but in general, the construction of these plants causes the formation of large artificial lakes, due to the impoundment of the rivers. The formation of artificial lakes has been the subject of some studies in Brazil (Fisch et al., 1990; Sanches and Fisch, 2005; Pereira et al., 2009), mainly due to changes that occur in the environment, and interferences that affect the populations that inhabit the areas that were flooded. The construction of a hydroelectric plant and the consequent formation of an artificial lake cause irreversible environmental impacts. Although hydroelectric plants use a renewable natural resource, which is water, they still alter the landscape due to deforestation, causing damage to the people, fauna and flora, flooding areas where they had residences, plantations, and animals, as well as the displacement of many families from their homes.

For the semiarid area of the Brazilian Northeast region (NEB), the developed microclimatic studies associated with the formation of the lake are still insufficient. Correia et al. (2006a,b) analyzed the soil occupation and atmospheric variations on the lake area of the Sobradinho Hydroelectric Power Plant (SHPP) in the state of Bahia inserted on the Sub-middle São Francisco River Basin (SFSB). It was found that changes resulting from the construction of a dam at a given location may lead to variations in the behavior of micrometeorological variables, such as wind, air temperature, and humidity. Analyses are performed using historical data series, comparing the periods before and after the filling of the lake, to evaluate the environmental impact caused by the formation of artificial lakes on the microclimate of a region.

The interest of the scientific community in the study of variability and climate change has increased in recent years, mainly due to the possible role of anthropogenic activity in the observed climate change, and their consequences in the most diverse sectors of human life (IPCC, 2014). When it comes to watersheds with multiple uses of water, projected climate changes are expected to alter the flow regime. The climatic conditions of reservoir management are among the main components of analysis in the face of future climate changes. Flow changes are also expected to have an impact on agriculture, including irrigation as well as more traditional agricultural practices in the region. For example, Adissu et al. (2015) affirm that agriculture is the most sensitive sector to climate changerelated hazards. According to Philip et al. (2014), climate change affects two of the most important direct agricultural production inputs (precipitation and temperature). Indirectly, climate change affects agriculture by influencing the emergence and distribution of crop pests and livestock diseases, decreasing water supplies and irrigation; and enhancing the severity of soil erosion (Watson, 2001).
Extreme climatic events in the region of the artificial Sobradinho Lake can cause severe damage not only in the agricultural sector but also to the regional economy. It is therefore crucial to understand possible impacts on reservoir operation and climate change (separately and together) on SFSB hydrology.

Researchers around the world agree on the direction of changing hydrological patterns in basins (lower flood spells and drier seasonal flows), but the magnitude of the change varies between studies due to different models and assumptions (Johnston and Kummu, 2012; Keskinen et al., 2012; Silva et al., 2015; Silva et al., 2016). In this context, the objective of this study is to provide new information on the trends of climatic extremes, dependent on rainfall and air temperature, for the SHPP lake region, through the analysis of climate change indices. The research focus is particularly important for the SHPP region because microclimate changes have significant impacts on the natural, social and economic sectors.

\section{Material and Methods}

\subsection{Study area}

The Sobradinho Hydroelectric Power Plant (SHPP) $\left(40^{\circ} 50 \mathrm{~W}, 9^{\circ} 35 \mathrm{~S}\right)$ is located in the municipality of Sobradinho, state of Bahia, Northeast Brazil, at a distance of about $40 \mathrm{~km}$ upstream from the cities of Juazeiro (Bahia state) and Petrolina (Pernambuco state). Built by the São Francisco Hydroelectric Company (CHESF), between 1973 and 1978, the plant began its operation in November 1979. The plant is located on the São Francisco River, the main river in the Northeast region of Brazil, with a hydrographic basin of $630,000 \mathrm{~km}^{2}$, and an extension of $3,200 \mathrm{~km}$, from its source in Serra da Canastra, in Minas Gerais state, to its mouth in Piaçabuçu (Alagoas state) and Brejo Grande (Sergipe state) (CHESF, 2016).

The SHPP is located $748 \mathrm{~km}$ from the mouth of the river. It is also the primary source of regularization of the region's water resources (CHESF, 2016). The lake is approximately $350 \mathrm{~km}$ long, with a water surface area of $4,214 \mathrm{~km}^{2}$ and a storage capacity of 34.1 billion $\mathrm{m}^{3}$ of water (Brazilian Committee of Dams, 2011).

This drainage basin has great altitude variation, from a minimum of $173 \mathrm{~m}$ to a maximum of $1280 \mathrm{~m}$, and an average of $506 \mathrm{~m}$, within a range of $1,107 \mathrm{~m}$ (Fig. 1). These relief characteristics denote that some areas of the basin would favor a massive loss of water by runoff as a function of slope ramp. Areas at altitudes between 350 and $400 \mathrm{~m}$ correspond to $17,605 \mathrm{~km}^{2}$, or $15.9 \%$ of the total area, being situated mainly within the central part of the basin, in the river channel. In contrast, altitudes between 400 and $450 \mathrm{~m}$ correspond to $24,705 \mathrm{~km}^{2}, 22.4 \%$ of the total area. Moreover, areas above $450 \mathrm{~m}$ account for more than $60,000 \mathrm{~km}^{2}$, i.e., $56 \%$ of the entire basin area (Silva et al., 2014). 

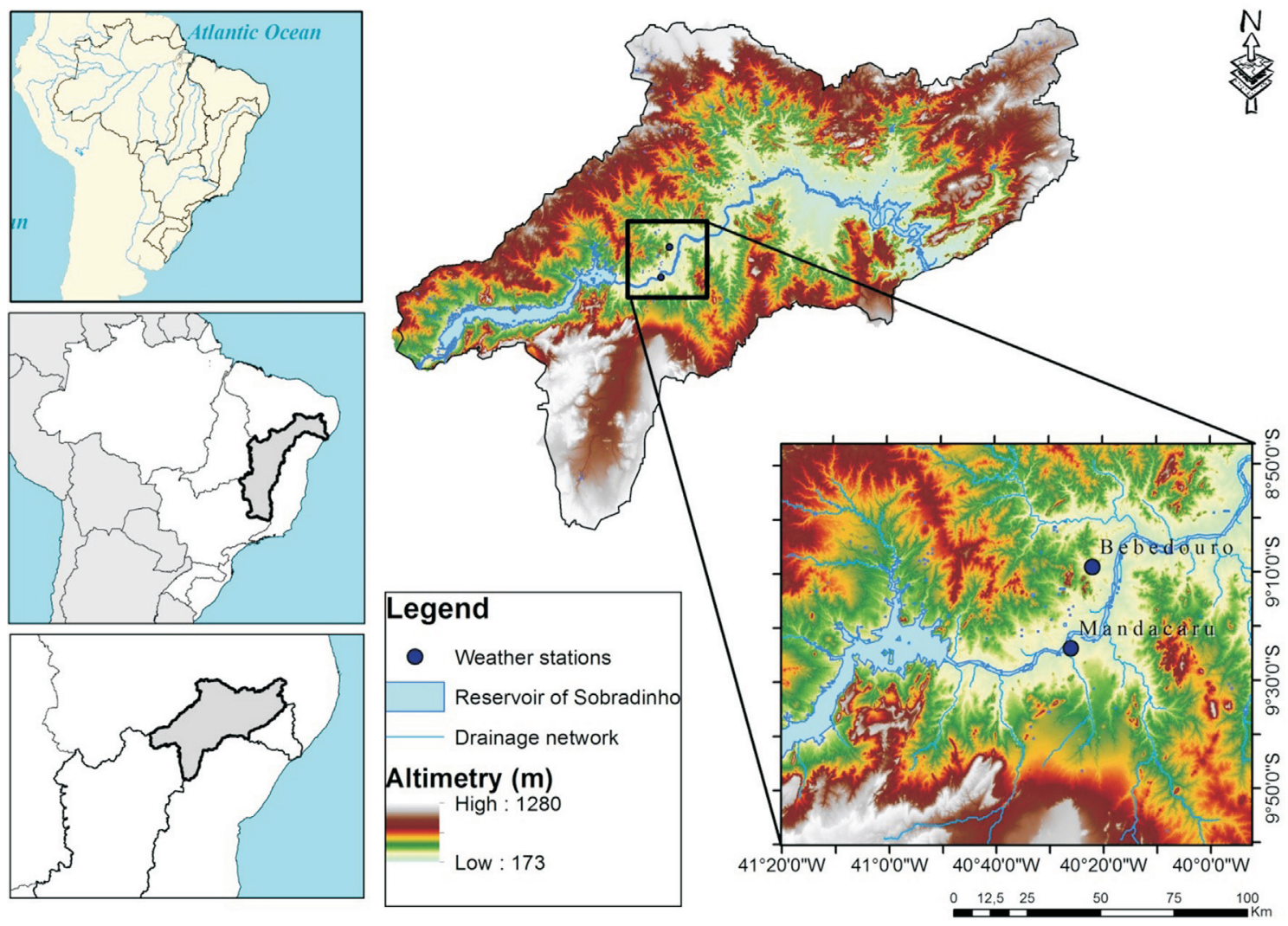

Figure 1 - Study area location.

\subsection{Methodology}

Daily rainfall and air temperature data for the period 1966-2014 were provided by the Agricultural Research Center of the Semiarid Tropic - Brazilian Agricultural Research Corporation (CPATSA - EMBRAPA). It was used data from two weather stations: Bebedouro, in Petrolina PE (09 $\left.09^{\prime} \mathrm{S} ; 40^{\circ} 22^{\prime} \mathrm{W}\right)$ and Mandacaru, in Juazeiro - BA $\left(09^{\circ} 24^{\prime} \mathrm{S} ; 40^{\circ} 26^{\prime} \mathrm{W}\right)$, the distance between these two weather stations is about $30 \mathrm{~km}$. The distance between the stations of Bebedouro and Mandacaru and the SHPP is of $65 \mathrm{~km}$ and $45 \mathrm{~km}$, respectively.

Data from monthly Sea Surface Temperature (SST) in the Equatorial Pacific Oceans - Niño $1+2\left(0^{\circ}-10^{\circ} \mathrm{S}\right.$, $\left.90^{\circ}-80^{\circ} \mathrm{W}\right)$, Niño $3\left(5^{\circ} \mathrm{N}-5^{\circ} \mathrm{S}, 150^{\circ}-90^{\circ} \mathrm{W}\right)$, Niño 3.4 $\left(5^{\circ} \mathrm{N}-5^{\circ} \mathrm{S}, 170^{\circ}-120^{\circ} \mathrm{W}\right)$ and Niño $4\left(5^{\circ} \mathrm{N}-5^{\circ} \mathrm{S}\right.$, $\left.160^{\circ} \mathrm{E}-150^{\circ} \mathrm{W}\right)(\mathrm{NCDC}-\mathrm{NOAA})$ and, North Atlantic Tropical (TNAI) $\left(5.5^{\circ}-23.5^{\circ} \mathrm{N}, 15^{\circ}-57.5^{\circ} \mathrm{W}\right)$ and the Southern Tropical Atlantic (TSAI) (Equator-20 S, 10 E$30 \mathrm{~W}$ ) (Met Office) for the period 1966-2014 were obtained from the Climate Prediction Center website of the National Oceanic and Atmospheric Administration (CPC - NOAA).

In this study, the climatic extremes indices were calculated using the software RClimdex, developed by Xuebin Zhang and Feng Yang for the Canadian Meteorological Service (Zhang and Yang, 2004), following the methodology of Zhang et al. (2005a,b) and Haylock et al. (2006). Twenty-two indices were calculated (11 for air temperature and 11 for precipitation analysis). As described in Nandintsetseg et al. (2007), data quality control or assurance refers to attempts by data processing personnel to minimize errors and possibly remove mistakes from an observation data set. It was used the RclimDex software package (ETCCDI Climate Change Indices), to "clean up" the daily precipitation and temperature data as shown by Huang et al. (2014).

Firstly, the process of "cleaning up" included (1) Negative daily precipitation amounts are set to missing values, and both daily maximum and minimum temperatures are set to missing values if the daily maximum temperature is less than the daily minimum temperature; (2) Next, the QC procedure identifies outliers in daily maximum and minimum temperatures and precipitation amounts. Outliers are daily values that lie outside a particular range defined as unrealistic by the user. For example, for temperature series, this range can be described as the mean value of observations for the day of the year plus or minus three or four times the standard deviation of the value for that calendar day in the entire series. Daily temperature values outside of these thresholds are marked as potentially erroneous and manually checked and corrected on a case-by-case basis. Each potential outlier can be evaluated using information from the days before and after the event along with expert knowledge about the local climate (Klein Tank et al., 2009). 
In this study, it was chosen three times the standard deviation of the value for that calendar day in the entire series because the temperature variability is small; (3) The generalized data plot was used within RclimDex to visually inspect data to further identify outliers and a variety of other problems that may cause error or bias in analyzing changes in the seasonal cycle or variance of the data; and (4) to detect artificial shifts that could exist in a time series it was used in the RHtestsV3 (Wang and Yang, 2010). After the quality control, it was used 49 years of meteorological data between January 1966 and December 2014 from the two stations. For this data series, there is less than $1 \%$ of missing data for both stations. In addition to the internal RClimdex tests, non-parametric tests were also used to identify if trends were statistically significant at the $5 \%$ and $1 \%$ level of probability.

The indices of climatic extremes, defined by ETCCDI, used in this research were those presented in Table 1. After obtaining the time series of the 22 indices of climatic extremes through the software RClimdex, it was necessary to use non-parametric tests to identify if the trends were statistically significant at the $5 \%$ and $1 \%$ probability level. The non-parametric tests used in this research were calculated using software R (version 3.3.1), and are described as follows:

\subsubsection{Mann-Kendall test}

The Mann-Kendall test (Sneyers, 1975) is the most appropriate method for analyzing climate change trends (Goossens and Berger, 1986). According to Sneyers (1975), it is considered that in the case of stability of a time series, the succession of independently occurring values, and the probability distribution must always remain the same (simple random series), thus it is tested the hypothesis $H_{0}$ : the observations of the series are independent and identically distributed, $H_{1}$ : the observations of the series have a monotonous trend in time. The $S$ statistic of the MannKendall test can be calculated according to Eq. (1):

$$
S=\sum_{k=1}^{n-1} \sum_{j=k+1}^{n} \operatorname{sign}\left(x_{j}-x_{k}\right)
$$

The signal can be obtained by Eqs. (2), (3) e (4):

$$
\begin{aligned}
& \operatorname{sign}\left(x_{j}-x_{k}\right)=1 \quad \text { if } \quad x_{j}-x_{k}>0 \\
& \operatorname{sign}\left(x_{j}-x_{k}\right)=0 \quad \text { if } \quad x_{j}-x_{k}=0 \\
& \operatorname{sign}\left(x_{j}-x_{k}\right)=-1 \quad \text { if } \quad x_{j}-x_{k}<0
\end{aligned}
$$

The $\mathrm{S}$ statistic approaches normality as $n$ increases, with mean and variance defined by:

$$
E(S)=0
$$

Table 1 - Definition of the indices of climatic extremes dependent on precipitation and air temperature used in this study.

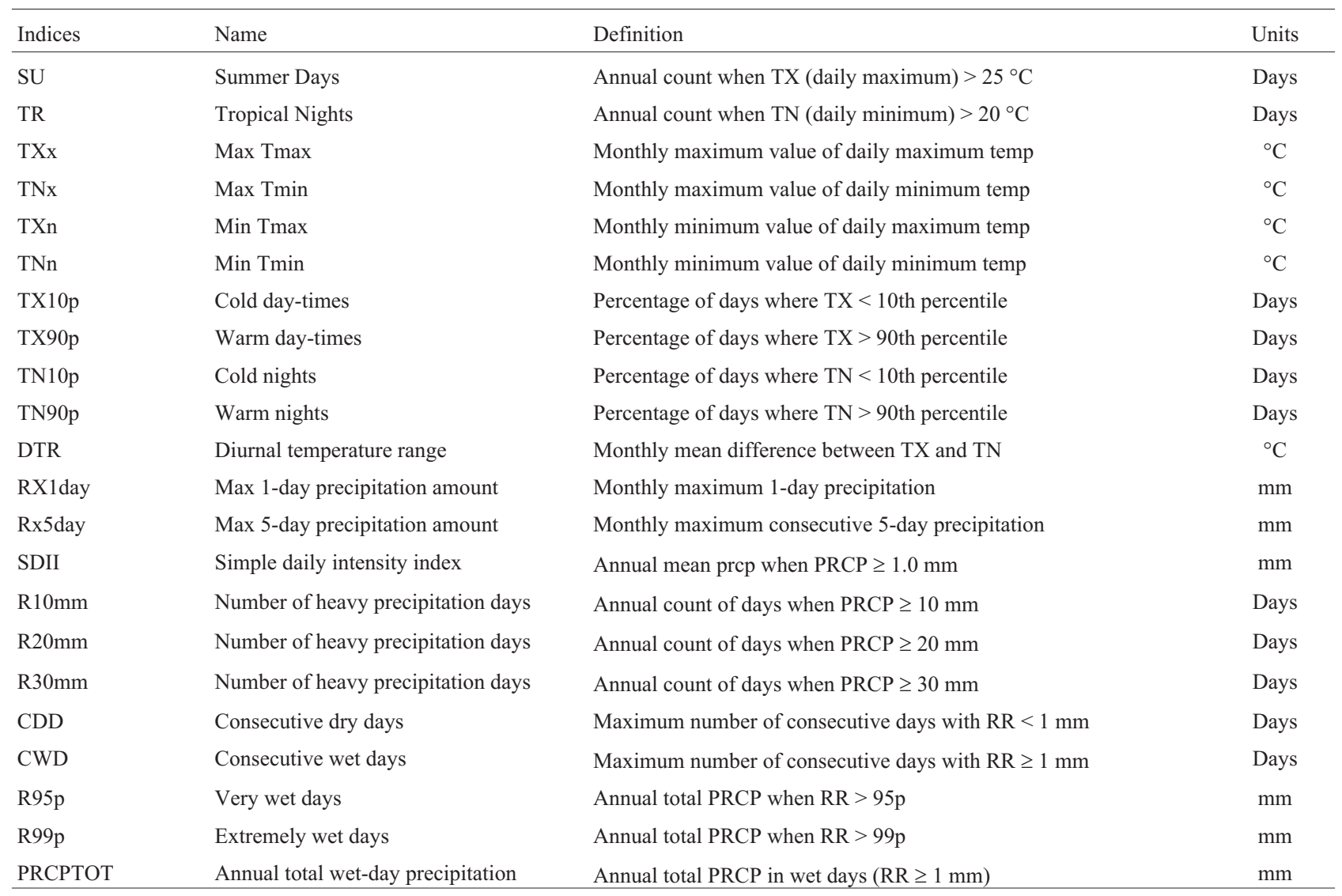


$\operatorname{Var}(S)=\frac{n(n-1)(2 n+5)-\sum_{i=1}^{m} t_{i}(i)(i-1)(2 i+5)}{18}$

The statistical test $Z(t)$, used to calculate the trend of a time series, was obtained by Eq. (7).

$$
Z(t)=\left\{\begin{array}{l}
\frac{S-1}{\sqrt{\operatorname{Var}(S)}}, \text { if } \quad S>0 \\
0, \quad \text { if } S=0 \\
\frac{S+1}{\sqrt{\operatorname{Var}(S)},} \text { if } \quad S<0
\end{array}\right.
$$

The null hypothesis of no trend, $H_{0}$, is rejected whenever $|Z(t)|>Z_{\alpha} / 2$ where $\alpha$ is the significance level adopted and $Z_{\alpha} / 2$ is the reduced normal variable of the standard normal distribution function, for values of $(Z(t)>0)$ increasing trends, for values of $(Z(t)<0)$ decreasing trends (Santos and Portela, 2008).

\subsubsection{Sen-Slope test}

From the value of the series, it was used the nonparametric test of Sen-Slope (Sen, 1968) to calculate the magnitude of the trend. This test provides an estimate of the slope $\left(T_{i}\right)$ of a change in measurement by the time change, as presented in Eq. (8):

$$
T_{i}=\frac{x_{j}-x_{k}}{j-k}, \text { for } \quad i=1,2,3, \ldots N
$$

where $T_{i}=$ slope between the data points $x_{j}$ and $x_{k} ; x_{j}=$ measurement of data in relation to time $j ; x_{k}=$ measurement of data in relation to time $k ; j=$ time after time $k$.

The median of these $N$ values of $T_{i}$ is represented as the Sen-Slope estimator, which is given as:

$$
T_{\text {med }}=\left\{\begin{array}{l}
\frac{T_{N+1}}{2}, N \text { is odd } \\
\frac{1}{2}\left(T_{\frac{N}{2}}+T_{\frac{N+2}{2}}\right), N \text { is even }
\end{array}\right.
$$

The Sen-Slope estimator is described as $T_{\text {med }}=T(N+1) / 2$ if $N$ is even if it is odd is considered as $T_{\text {med }}=\left[\frac{T_{N}}{2}+\frac{T_{N+2}}{2}\right] / 2$.

Finally, $T_{m e d}$ was calculated by a two-sided test in $100(1-\alpha) \%$ confidence interval, and then the slope was obtained by the non-parametric test. $T_{m e d}$ positive values indicate increasing or upward trend, and negative values of $T_{\text {med }}$ indicate decreasing or downward trend of the time series. The null hypothesis $\left(H_{0}\right)$ means that there is no slope over time, and the alternative hypothesis $\left(H_{1}\right)$ is that there is an increasing or decreasing slope in the series.

\subsubsection{Pettitt test}

The Pettitt test was used to locate an abrupt change in the mean of the data series. This test consists of verifying if two samples $x_{l}, \ldots x_{t}$ and $x_{t+1}, \ldots, x_{T}$ are of the same population. According to Pettitt (1979), the statistic $U_{t, T}$ can be calculated using Eq. (10).

$$
U_{t, T}=U_{t-1, T}+\sum_{j=1}^{T} \operatorname{sign}\left(x_{t}-x_{i}\right),
$$

for $t=2, \ldots N$, where $\operatorname{sign}(x)=\left\{\begin{array}{lll}1, & \text { if } & x>0 \\ 0, & \text { if } & x=0 \\ -1, & \text { if } & x<0\end{array}\right.$

When there is no link in the data, $V_{t, T}=T+1-2 R_{t}$, where $R_{t}$ is the order of $x_{t}$ in the sample. The statistic $k_{t}$ gives the point where an abrupt change occurs in the mean of the data series:

$$
k_{t}=M A X I \leq t \leq T\left|U_{t, T}\right|
$$

The significance is calculated by Eq. (12).

$$
p \approx 2 \exp \left\{-6 k_{t^{2}} /\left(T^{3}+T^{2}\right)\right\}
$$

The null hypothesis $\left(H_{0}\right)$ indicates no abrupt change over time and the alternative hypothesis $\left(H_{1}\right)$ is that there is an abrupt change in the time series.

\subsubsection{Spearman correlation}

To analyze the behavior of the climate extremes indices in the SHPP region and the relation of dependence of these indices with the SST of the Equatorial Pacific and SST anomalies Tropical Atlantic Oceans, the Spearman method was used.

This correlation was used for non-parametric tests. Thus, this coefficient is not sensitive to asymmetries in the distribution, nor to the presence of outliers, and does not require that data come from two normal populations. The null hypothesis $\left(H_{0}\right)$ is that $\rho=0$ and the alternative hypothesis $\left(H_{1}\right)$ is that $\rho \neq 0$. The Spearman correlation coefficient was obtained by Eq. (13).

$$
\rho=1-\frac{6 \sum_{i=1}^{n} d_{i}^{2}}{n\left(n^{2}-1\right)}
$$

where $\rho$ is the Spearman correlation coefficient; $d_{i}$ is the difference between the ordinations; $n$ is the number of ordered pairs.

For samples greater than 20 observations, the following approximation can be used for the Student $t$ distribution:

$$
t=\frac{\rho}{\sqrt{\left(1-\rho^{2}\right)(n-2)}}
$$

where the distribution thas $n-2$ degrees of freedom.

The RClimdex script, as well as the R software, is freely downloadable through the sites (ETCCDI Climate Change Indices) and (The R Project for Statistical Computing), respectively. 


\section{Results and Discussion}

\subsection{Climate change indices}

The trends of the 22 indices of climatic extremes were obtained for the Bebedouro-PE and Mandacaru-BA weather stations. Tables 2 and 3 present the values of the trends dependent on air temperature and rainfall, respectively, for the two stations, based on the results of the non-parametric Mann-Kendall, Sen-Slope and Pettitt tests. The values in bold and highlighted in gray presented statistical significance at $1 \%$ level $(p<0.01)$ and the values only highlighted in gray presented statistical significance at the $5 \%$ level $(\mathrm{p}<0.05)$.

The advantage of using these tests is that they filter the extreme values of the data series. In Tables 2 and 3, the result of the Mann-Kendall test is presented with the values of the S-statistic, p-value and Z-statistical test. The values of the slope $\left(\mathrm{T}_{\mathrm{i}}\right)$ of the time series obtained by the SenSlope test are also presented in these two tables, as well as the value of the statistical test $K(t)$, its p-value and the year of possible abrupt change in the time series, calculated by the Pettitt test.
Observing Table 2, it can be noticed that all indices depending on air temperature for the Bebedouro-PE station presented results with statistical significance. The air temperature indices SU, TR, TXx, TXn, TNx, TX10p, TX90p, TN10p and TN90p showed statistical significance at 1\% level and, TNn and DTR at 5\% level. For the precipitation indices, only five presented significant results, such as SDII, R10mm, R20mm and PRCPTOT with statistical significance at $1 \%$ level and R95p with statistical significance at 5\% level. Table 3 shows the results obtained for Mandacaru-BA station where ten air temperature indices (SU, TR, TXx, TXn, TNn, TX10p, TX90p, TN10p, DTR, and TN90p) showed statistical significance at 5\% level. The precipitation indices did not present statistical significance.

The results obtained from the air temperature trends for the Bebedouro-PE station (Table 2) show increasing trends in 9 of the 11 indices. The hot days index (SU) (Fig. 2a) shows an increasing trend of 0.038 days/year (i.e., increase of about four days with daily maximum temperatures above $25^{\circ} \mathrm{C}$ in 100 years). There was also an increase in the frequency of warm nights (TR) (Fig. 2b) in the Bebedouro-PE station, with a trend of 1.5 days/year. This result indicates that in 30 years, for example, there may be

Table 2 - Results of the non-parametric Mann-Kendall, Sen-Slope and Pettitt tests for the Bebedouro-PE station, for the indices dependent on the air temperature and precipitation, in the period 1966-2014.

\begin{tabular}{|c|c|c|c|c|c|c|c|}
\hline \multirow[t]{2}{*}{ Indices } & \multicolumn{3}{|c|}{ Mann-Kendall } & \multirow{2}{*}{$\begin{array}{c}\text { Sen-Slope } \\
T_{i}\end{array}$} & \multicolumn{3}{|c|}{ Pettitt } \\
\hline & $S$ & $\mathrm{p}$-value & $Z(S)$ & & $K(t)$ & p-value & Year of abrupt change \\
\hline SU (Dias) & 298 & 0.008 & 2.6 & 0.038 & 251 & 0.085 & 1978 \\
\hline TR (Dias) & 397 & $<0.001$ & 3.4 & 1.500 & 304 & 0.019 & 1981 \\
\hline $\mathrm{TXx}\left({ }^{\circ} \mathrm{C}\right)$ & 290 & 0.011 & 2.5 & 0.019 & 271 & 0.050 & 1993 \\
\hline $\operatorname{TXn}\left({ }^{\circ} \mathrm{C}\right)$ & 349 & 0.002 & 3 & 0.033 & 293 & 0.027 & 1992 \\
\hline $\mathrm{TNx}\left({ }^{\circ} \mathrm{C}\right)$ & 352 & 0.002 & 3 & 0.028 & 245 & 0.099 & 1990 \\
\hline $\mathrm{TNn}\left({ }^{\circ} \mathrm{C}\right)$ & 270 & 0.020 & 2.3 & 0.023 & 214 & 0.200 & 1997 \\
\hline TX10p (Dias) & -570 & $<0.001$ & -4.9 & -0.416 & 472 & $<0.001$ & 1992 \\
\hline TX90p (Dias) & 606 & $<0.001$ & 5.2 & 0.372 & 456 & $<0.001$ & 1992 \\
\hline TN10p (Dias) & -460 & $<0.001$ & -4 & -0.390 & 346 & 0.005 & 1981 \\
\hline TN90p (Dias) & 436 & $<0.001$ & 3.7 & 0.354 & 308 & 0.017 & 1993 \\
\hline $\operatorname{DTR}\left({ }^{\circ} \mathrm{C}\right)$ & 245 & 0.035 & 2.1 & 0.013 & 321 & 0.011 & 1989 \\
\hline RX1day (mm) & -162 & 0.165 & -1.4 & -0.408 & 196 & 0.293 & 1984 \\
\hline RX5day (mm) & -194 & 0.096 & -1.7 & -0.669 & 208 & 0.230 & 1985 \\
\hline SDII (mm) & -290 & 0.012 & -2.5 & -0.053 & 240 & 0.112 & 1984 \\
\hline R10mm (Dias) & -284 & 0.014 & -2.4 & -0.142 & 206 & 0.239 & 1997 \\
\hline R20mm (Dias) & -278 & 0.016 & -2.4 & -0.097 & 237 & 0.120 & 1985 \\
\hline R30mm (Dias) & -131 & 0.245 & -0.11 & 0 & 181 & 0.389 & 1984 \\
\hline CDD (Dias) & 1 & 1 & 0 & 0 & 113 & - & - \\
\hline CWD (Dias) & -183 & 0.108 & -1.6 & 0 & 178 & 0.410 & 1992 \\
\hline $\mathrm{R} 95 \mathrm{p}(\mathrm{mm})$ & -240 & 0.039 & -0.2 & -1.953 & 218 & 0.186 & 1984 \\
\hline R99p (mm) & -147 & 0.270 & -0.12 & 0 & 198 & 0.281 & 1984 \\
\hline PRCPTOT (mm) & -302 & 0.009 & -2.6 & -5.560 & 238 & 0.117 & 1985 \\
\hline
\end{tabular}


Table 3 - Results of the non-parametric Mann-Kendall, Sen-Slope and Pettitt tests for the Mandacaru-BA station, for the indices dependent on the air temperature and precipitation, in the period 1966-2014.

\begin{tabular}{|c|c|c|c|c|c|c|c|}
\hline \multirow[t]{2}{*}{ Indices } & \multicolumn{3}{|c|}{ Mann-Kendall } & \multirow{2}{*}{$\begin{array}{c}\text { Sen-Slope } \\
T_{i} \\
\end{array}$} & \multicolumn{3}{|c|}{ Pettitt } \\
\hline & $S$ & $\mathrm{p}$-value & $Z(S)$ & & $K(t)$ & $\mathrm{p}$-value & Year of abrupt change \\
\hline SU (Dias) & 472 & $<0.001$ & 4.1 & 0.100 & 377 & 0.001 & 1981 \\
\hline TR (Dias) & -279 & 0.016 & -2.4 & -1.372 & 369 & 0.002 & 1999 \\
\hline $\mathrm{TXx}\left({ }^{\circ} \mathrm{C}\right)$ & 413 & $<0.001$ & 3.6 & 0.033 & 410 & $<0.001$ & 1995 \\
\hline $\mathrm{TXn}\left({ }^{\circ} \mathrm{C}\right)$ & 388 & $<0.001$ & 3.3 & 0.047 & 327 & 0.009 & 1979 \\
\hline $\mathrm{TNx}\left({ }^{\circ} \mathrm{C}\right)$ & -19 & 0.876 & -0.2 & 0 & 180 & 0.396 & 1999 \\
\hline $\mathrm{TNn}\left({ }^{\circ} \mathrm{C}\right)$ & -407 & $<0.001$ & -3.5 & -0.040 & 405 & $<0.001$ & 1998 \\
\hline TX10p (Dias) & -596 & $<0.001$ & -5.1 & -0.403 & 468 & $<0.001$ & 1992 \\
\hline TX90p (Dias) & 628 & $<0.001$ & 5.4 & 0.530 & 518 & $<0.001$ & 1995 \\
\hline TN10p (Dias) & 292 & 0.012 & 2.5 & 0.317 & 375 & 0.001 & 1999 \\
\hline TN90p (Dias) & -221 & 0.057 & -1.9 & -0.145 & 388 & 0.001 & 1998 \\
\hline $\operatorname{DTR}\left({ }^{\circ} \mathrm{C}\right)$ & 618 & $<0.001$ & 5.3 & 0.060 & 544 & $<0.001$ & 1996 \\
\hline RX1day (mm) & -44 & 0.710 & -0.4 & -0.096 & 148 & 0.669 & 1992 \\
\hline RX5day (mm) & -36 & 0.762 & -0.3 & -0.133 & 196 & 0.293 & 1992 \\
\hline SDII (mm) & 39 & 0.743 & 0.3 & 0.018 & 149 & 0.659 & 1971 \\
\hline R10mm (Dias) & -72 & 0.538 & -0.6 & 0 & 118 & 0.997 & 1981 \\
\hline R20mm (Dias) & -64 & 0.584 & -0.5 & 0 & 150 & 0.649 & 1980 \\
\hline R30mm (Dias) & -163 & 0.151 & -1.4 & 0 & 208 & 0.230 & 1981 \\
\hline CDD (Dias) & 17 & 0.890 & 0.1 & 0.083 & 162 & 0.538 & 1977 \\
\hline CWD (Dias) & 30 & 0.797 & 0.3 & 0 & 113 & - & - \\
\hline $\mathrm{R} 95 \mathrm{p}(\mathrm{mm})$ & -97 & 0.406 & -0.8 & -0.787 & 169 & 0.479 & 1981 \\
\hline R99p (mm) & 75 & 0.433 & 0.8 & 0 & 150 & 0.649 & 1975 \\
\hline PRCPTOT $(\mathrm{mm})$ & -97 & 0.407 & -0.8 & -1.722 & 160 & 0.556 & 1980 \\
\hline
\end{tabular}

an increase of 45 nights in a year where the temperature will be higher than $20^{\circ} \mathrm{C}$. The maximum maximum temperature (TXx) (Fig. 2c), minimum maximum temperature (TXn) (Fig. 2d), maximum minimum temperature (TNx) (Fig. 2e) and minimum minimum temperature (TNn) (Fig. 2f) showed trend values of $0.019 ; 0.033 ; 0.028$ and $0.023{ }^{\circ} \mathrm{C} /$ year, respectively. These results indicate a trend of increase for both the maximum and minimum temperature in the Bebedouro-PE station.

It is possible to observe a gradual increase in the maximum and minimum temperatures during the last decades, which can be identified through the temporal distributions of these indices. These results agree with those found by Lima et al. (2011) and Silva e Azevedo (2008) that used statistical tests to verify trends of climatic changes for the state of Bahia. The increase in maximum and minimum temperatures in the region of study corroborates with the projections of the IPCC (2013) which has identified that minimum temperatures have increased faster than maximum temperatures.

With the increase in maximum and minimum temperatures and in the occurrence of hot days and nights, it is expected that the occurrence of cold days and night will decrease. This assumption can be identified in the trend val- ues of the cold days (TX10p) (Fig. 2g) and cold nights (TN10p) (Fig. 2i) indices, where these indices present a reduction of 0.416 and 0.390 days/year, respectively. Additionally, the hot days (TX90p) (Fig. 2h) and hot nights (TN90p) (Fig. 2k) indices agree with the SU and TR indices mentioned above and indicate an increase in hot days and nights, where trend values are 0.372 and 0.354 days/year, respectively. The diurnal temperature range (DTR) (Fig. 2l) is increasing with a trend of $0.016^{\circ} \mathrm{C} /$ year.

The results obtained from the rainfall trends for the Bebedouro-PE station (Table 2) showed a decrease of this variable in 7 of the 11 indices studied, 5 presented significant values $(\mathrm{p}<0.05)$, such as SDII, R10mm, R20mm, PRCPTOT, and R95p. A statistically significant decrease in the number of days with precipitation equal or greater than $10 \mathrm{~mm}$ (R10mm) (Fig. 3a) and $20 \mathrm{~mm}$ (Fig. 3b) was identified for the Bebedouro-PE station (Table 2); with values of these trends being 0.142 and 0.097 days/year, respectively. The annual total precipitation (PRCPTOT) (Fig. 3c) is decreasing about $5.6 \mathrm{~mm} /$ year, with a linear projection for the next three decades, and the total precipitation would reduce by approximately $170 \mathrm{~mm}$ in 30 years.

The simple daily intensity index (SDII) (Fig. 3d), which is the ratio of total annual precipitation to the number 

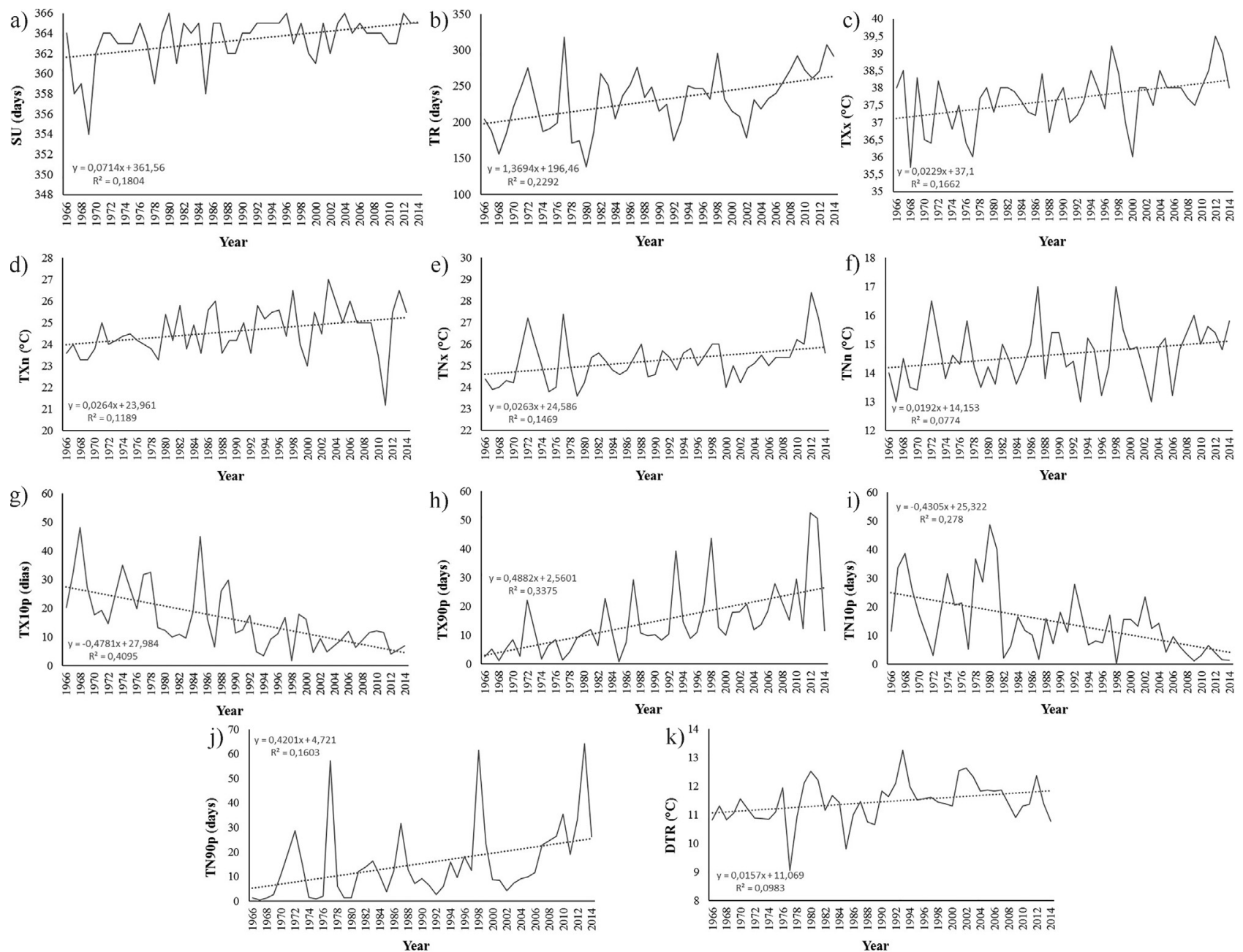

Figure 2 - Annual variability of the statistically significant temperature extremes indices for the Bebedouro-PE station for the period 1966 to 2014 , where: a) SU, b) TR, c) TXx, d) TXn, e) TNx, f) TNn, g) TX10p, h) TX90p, i) TN10p, j) TN90p and k) DTR.

of days with precipitation in one year, agrees with the rates mentioned above and decreases with a value of $0.053 \mathrm{~mm} /$ year. Therefore, it is observed that the decrease in rainfall greater than or equal to $10 \mathrm{~mm}$ and $20 \mathrm{~mm}$ agrees with the reduction of total precipitation, as well as with the reduction of the SDII. The index very humid (R95p) (Fig. 3e) also shows a trend of decrease to Bebedouro, with a value of $1.953 \mathrm{~mm} / \mathrm{year}$, which can lead to a linear trend of reduction of approximately $60 \mathrm{~mm}$ in 30 years.

The first report of the Brazilian Panel on Climate Change (PBMC, 2014) projects a significant decrease in rainfall in most of the Central, North and Northeast regions of Brazil, and these changes may accentuate from the middle and end of the XXI century, agreeing with the IPCC's special report on extreme climatic events (IPCC, 2012), which projects a higher frequency of more intense and prolonged dry periods to the Northeast Brazil and the Amazon regions, which may lead to seasonal droughts. Statistically significant results for the Bebedouro-PE station agree with the IPCC and PBMC projections, indicating a decrease in precipitation for this region.

By applying the Pettitt test, it was possible to obtain the point at which the abrupt change occurred in the time series (last column of Tables 2 and 3). Table 2 shows that only the indices based on the air temperature for Bebedouro - PE are significant at the $1 \%$ level, such as TR, TX10p, TX90p, TN10p, TN90p, and DTR, as well as TXX and TXn indices at $5 \%$ level. Similarly, the results obtained from the air temperature trends for the Mandacaru-BA station (Table 3) were statistically significant at $5 \%$ level in 10 of the 11 indices obtained, such as SU, TR, TXx, TXn, TNn, TX10p, TX90p, TN10p, DTR, and TN90p. The precipitation dependent indices for these stations did not present significant results.

The Sen-Slope test is intended to obtain the magnitude of the trend in the historical series. Tables 2 and 3 show the slope values $\left(T_{i}\right)$ of the data series. Positive values indicate an upward trend and negative values provide the downward trend of the dataset. The SU index (Fig. 4a) for 
a)

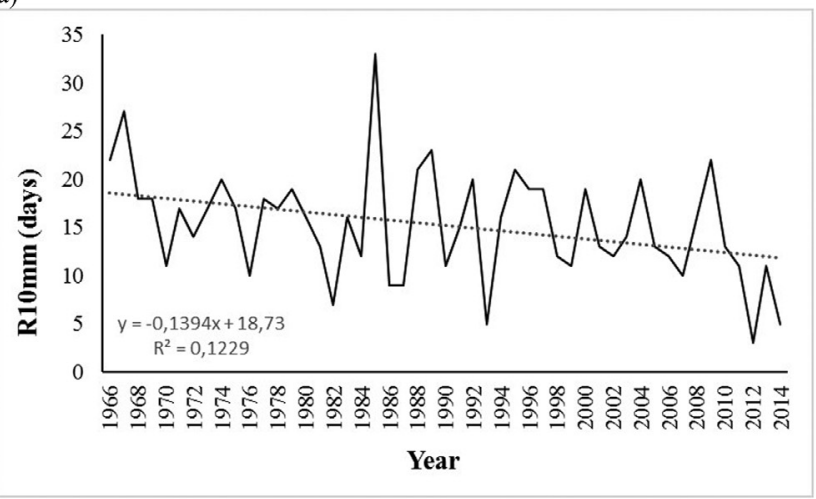

c)

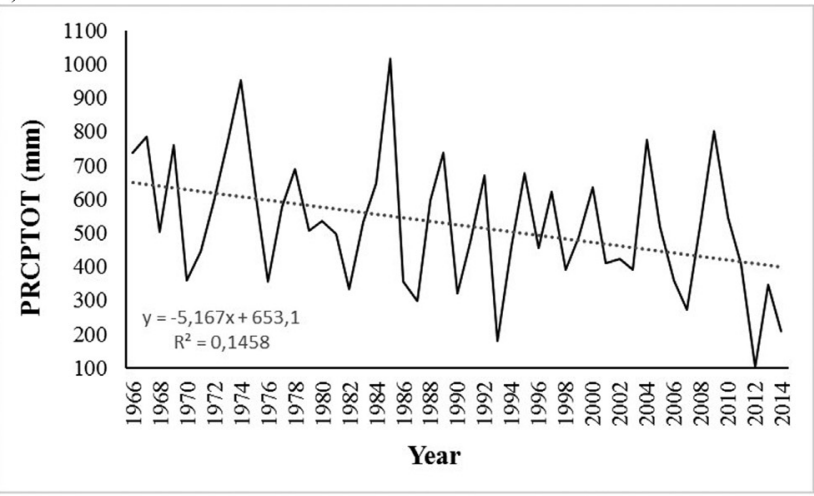

b)

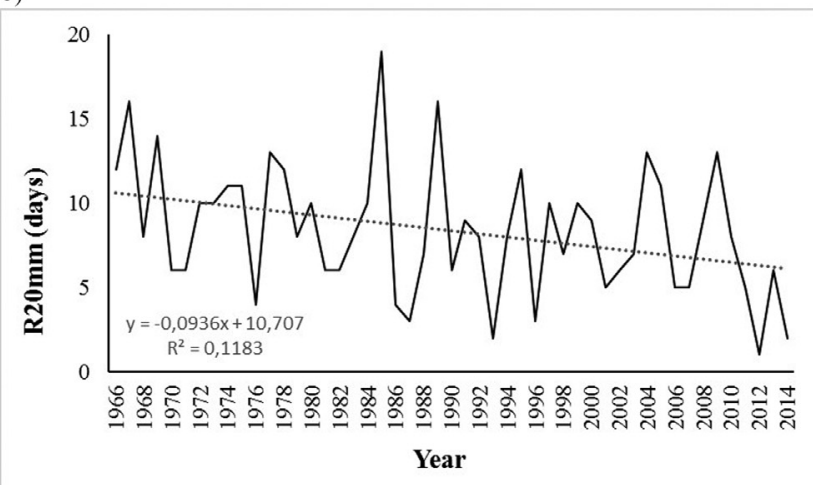

d)

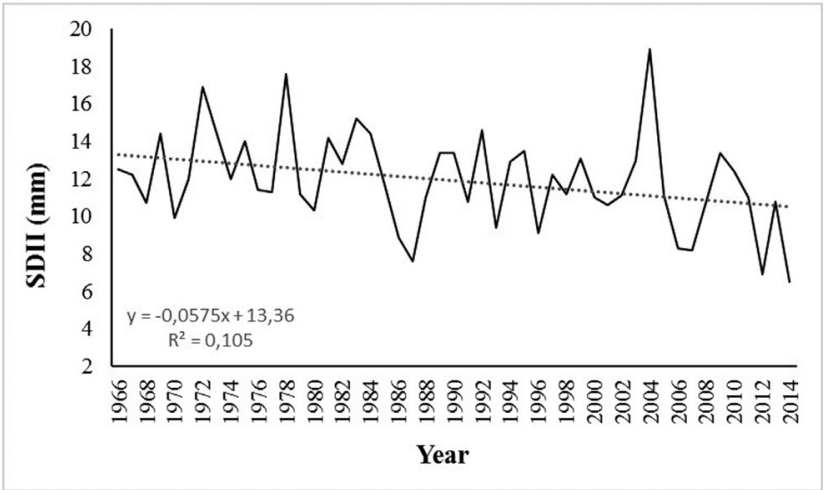

e)

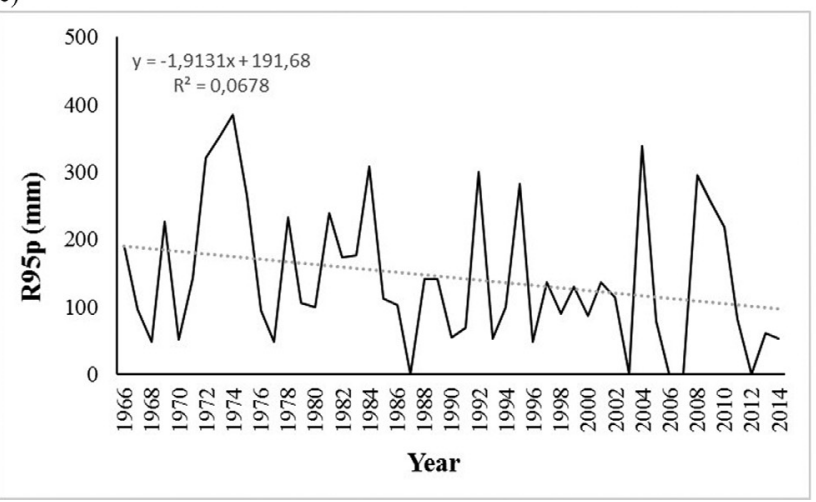

Figure 3 - Annual variability of the statistically significant precipitation extremes indices for the Bebedouro-PE station for the period 1966 to 2014 , where: a) R10mm, b) R20mm, c) PRCPTOT, d) SDII and e) R95p.

the Mandacaru-BA station, as well as for the BebedouroPE station, showed an increasing trend, with a value of 0.1 days/year. However, for TR index (Fig. 4b), unlike the results obtained for Bebedouro-PE, there is a decreasing trend with a value of 1.372 days/year, indicating that in 30 years, for example, there may be a decrease of about 41 warm nights (temperature higher than $20^{\circ} \mathrm{C}$ ) in a year. The indices referring to the maximum temperature indicate an increasing trend during the studied period. The TXx (Fig. 4c) and TXn (Fig. 4d) indices are increasing 0.033 and $0.047^{\circ} \mathrm{C} /$ year, respectively. The TXn index is increasing faster than the TNn (Fig. 4e) index which shows a reduction of $0.040{ }^{\circ} \mathrm{C} /$ year. The TX10p (Fig. 4f), TX90p (Fig. 4g), TN10p (Fig. 4h) and TN90p (Fig. 4i) indices show trend values of $-0.403,0.530,0.317$ and -0.145 days/year, respectively. The TN90p index agrees with the result obtained for the TR index, both indicating a decrease in the hot nights in the Mandacaru station region. There is also a downward trend of cold days, as shown by the trend value of the TX10p index. The DTR index (Fig. 4j) is increasing $0.06^{\circ} \mathrm{C} /$ year.

The results obtained from the rainfall trends for the Mandacaru-BA station (Table 3) did not present statistical significance for any index, however, in general, it is possi- 

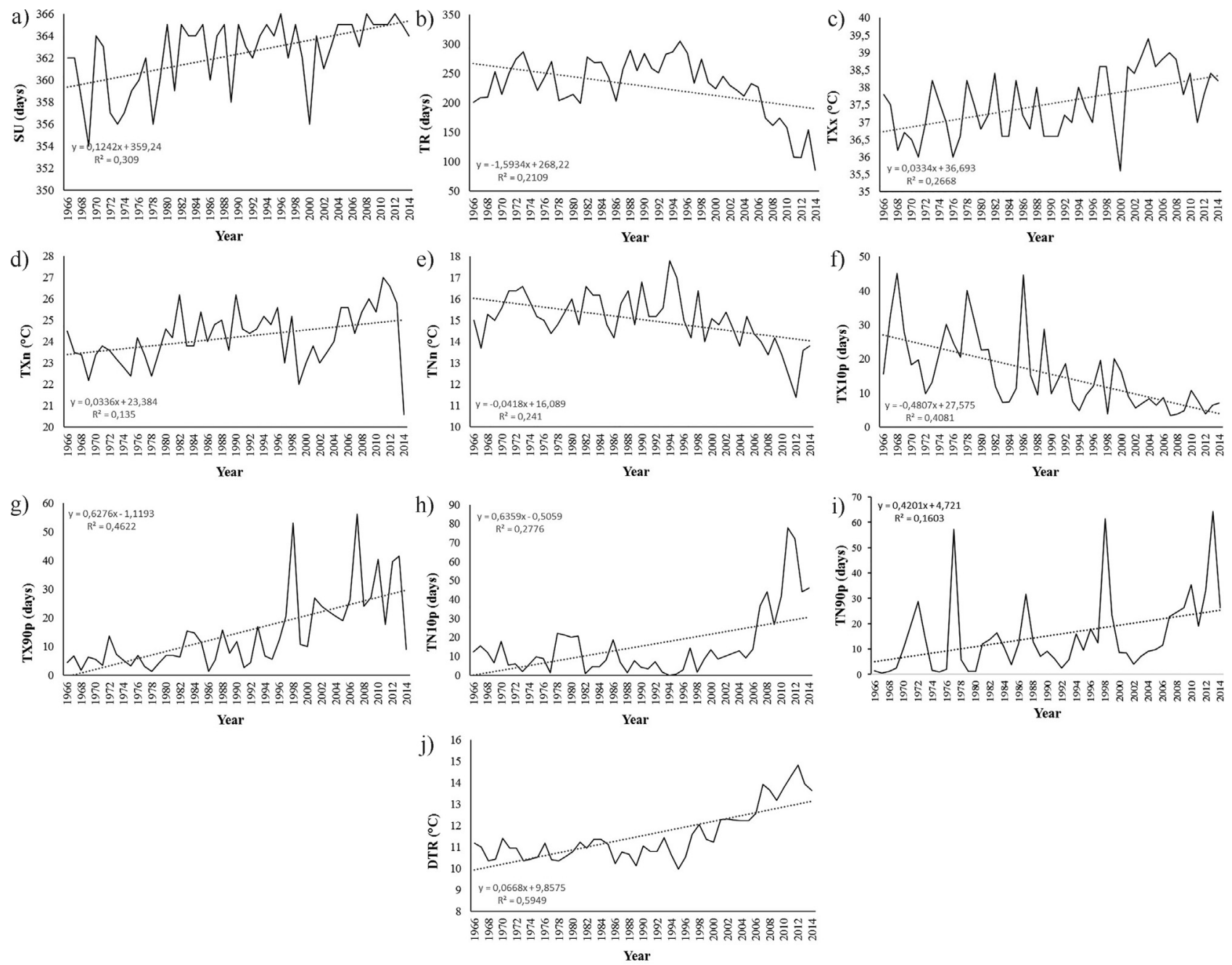

Figure 4 - Annual variability of the statistically significant temperature extremes indices for the Mandacaru-BA station for the period 1966 to 2014 , where: a) SU, b) TR, c) TXx, d) TXn, e) TNn, f) TX10p, g) TX90p, h) TN10p, i) TN90p and j) DTR.

ble to observe decrease trends, as well as in Bebedouro - PE station. Of the 11 indices dependent on precipitation, 7 presented a precipitation decreasing trend. Precipitation is a determinant variable of the climatic conditions in the Brazilian semi-arid, and the analysis of its behavior is of great importance, due to the great irregularity presented in temporal and spatial scales, not only under the climatic approach but also due to the consequences in the socioeconomic sector, as well as in the population comfort.

The considerable spatial and temporal variability of the precipitation justifies the fact that few indices have significant values in the Bebedouro-PE station and no index at the Mandacaru-BA station. The results of precipitation trends for the two stations used in this study indicate, in general, a decrease in the values of this variable in the SHPP region, but few indices presented significant results.

The trends of climatic extremes of temperature for Bebedouro-PE showed an increase in maximum and minimum temperatures, the number of hot days and nights, diurnal temperature range and, consequently, a reduction in cold days and nights. For Mandacaru-BA, temperature trends presented some results contrary to Bebedouro. The warm nights are decreasing in Mandacaru as well, the extreme minimum temperature; already the hot days are increasing.

The results for the two stations agree on the trend of increase to the maximum temperature, number of hot days and on the diurnal temperature range, which led to the decrease in the occurrence of cold days. These increases can lead to different consequences for that region, which encompasses several irrigation agriculture areas and two important expanding cities (Petrolina-PE and Juazeiro-BA).

\subsection{Climate change indices and SST}

In order to better understand the relationship between the SST of the Equatorial Pacific and Tropical Atlantic oceans and precipitation in NEB, several studies have been developed (Uvo et al., 1998; Andreoli and Kayano, 2007; Rodrigues et al., 2011; Araújo e Brito 2011; Kayano et al., 2016). Araújo and Brito (2011) verified the influence of 
SST of the Pacific and Atlantic oceans on precipitation in the states of Bahia and Sergipe. Andreoli and Kayano (2007) observed that the impact of the Tropical Atlantic on the variability of NEB precipitation is more marked for the variability of SST in the South Atlantic when compared to that of the North Atlantic.

In this study, the climate change indices were individually correlated with the SST of the Equatorial Pacific (Niño 1+2, Niño 3, Niño 3.4 and Niño 4) regions and the SST of the Northern Tropical Atlantic Index (TNAI) and Southern Tropical Atlantic Index (TSAI). Statistical significant correlations at 5 and $1 \%$ levels $(p<0.05$ and $p<0.01)$ are presented in Tables 4 and 5. The bolded and highlighted in gray values presented statistical significance at $1 \%$ level and the highlighted in gray values presented statistical significance at $5 \%$ level.

Table 4 shows the correlations between the trends of the climate change indices for the station of Bebedouro-PE and the regions of the Equatorial Pacific. Five indices depending on the air temperature have positive correlations, indicating that an increase in SST in the Equatorial Pacific can cause an increase in air temperature in Bebedouro-PE.

We calculated the annual mean SST and then correlated with the SU index. The SU index shows positive cor- relations for the four SST regions in the Pacific Ocean, indicating that an increase in SST of these regions implies an increase in the number of hot days in the SHPP region. The TXx index showed significant correlations with the areas of Niño 3, Niño 3.4 and Niño 4, indicating that an increase in the SST of these regions can cause an increase in the maximum daily temperature. The TXn index has significant correlations with the Niño $1+2$ region and with the other areas, showing that an increase in this index is related with the SST increases in these regions. The positive correlation between the TX90p index and the Niño 1+2 and Niño 3 regions indicates an increase in hot days, as the SST of these regions increases, agreeing with the results of the correlations for the SU index.

An increase in hot days and maximum temperature as the SST becomes hotter also agrees with the result of correlations between the four Pacific Ocean regions and the DTR index. This index presents a significant positive association with the Niño 3, Niño 3.4 and Niño $1+2$ regions. Indicating that an increase in the SST of these three regions can imply an increase in the diurnal temperature range.

For indices dependent on rainfall, only CDD showed a significant correlation. For the regions Niño 3, Niño 3.4 and Niño 4 , significant at the $1 \%$ level and, for Niño $1+2$, at

Table 4 - Correlations between the annual averages of the indices of extremes of air temperature and precipitation and the annual mean Sea Surface Temperature (SST) in the regions of the Equatorial Pacific and the annual mean anomalies of SST Tropical Atlantic Oceans, for the station of Bebedouro-PE, in the period 1966-2014.

\begin{tabular}{|c|c|c|c|c|c|c|}
\hline Indices & Niño $1+2$ & Niño 3 & Niño 3.4 & Niño 4 & TNAI & TSAI \\
\hline SU (Days) & 0.424 & 0.432 & 0.399 & 0.382 & 0.159 & 0.062 \\
\hline TR (Days) & 0.248 & 0.223 & 0.087 & 0.058 & 0.173 & 0.385 \\
\hline $\mathrm{TXx}\left({ }^{\circ} \mathrm{C}\right)$ & 0.278 & 0.437 & 0.383 & 0.400 & 0.522 & 0.024 \\
\hline $\mathrm{TXn}\left({ }^{\circ} \mathrm{C}\right)$ & 0.382 & 0.340 & 0.310 & 0.356 & 0.184 & 0.193 \\
\hline $\mathrm{TNx}\left({ }^{\circ} \mathrm{C}\right)$ & 0.196 & 0.188 & 0.093 & 0.078 & 0.181 & 0.258 \\
\hline $\mathrm{TNn}\left({ }^{\circ} \mathrm{C}\right)$ & 0.262 & 0.194 & 0.060 & 0.025 & 0.031 & 0.195 \\
\hline TX10p (Days) & -0.466 & -0.505 & -0.406 & -0.454 & -0.489 & -0.190 \\
\hline TX90p (Days) & 0.491 & 0.444 & 0.281 & 0.262 & 0.519 & 0.386 \\
\hline TN10p (Days) & -0.300 & -0.312 & -0.180 & -0.167 & -0.254 & -0.374 \\
\hline TN90p (Days) & 0.245 & 0.198 & 0.052 & 0.016 & 0.274 & 0.384 \\
\hline $\operatorname{DTR}\left({ }^{\circ} \mathrm{C}\right)$ & 0.333 & 0.369 & 0.370 & 0.391 & 0.339 & -0.210 \\
\hline RX1day (mm) & -0.064 & -0.155 & -0.145 & -0.200 & -0.230 & -0.070 \\
\hline RX5day (mm) & -0.085 & -0.091 & -0.080 & -0.160 & -0.136 & -0.018 \\
\hline SDII (mm) & 0.020 & 0.000 & 0.042 & -0.053 & -0.201 & -0.116 \\
\hline R10mm (Days) & -0.340 & -0.266 & -0.183 & -0.149 & -0.138 & 0.018 \\
\hline R20mm (Days) & -0.236 & -0.188 & -0.105 & -0.111 & -0.121 & -0.014 \\
\hline R30mm (Days) & 0.100 & -0.017 & -0.034 & -0.126 & -0.180 & 0.031 \\
\hline CDD (Days) & 0.302 & 0.371 & 0.398 & 0.381 & 0.099 & -0.117 \\
\hline CWD (Days) & -0.159 & -0.116 & -0.016 & -0.031 & -0.027 & -0.192 \\
\hline $\mathrm{R} 95 \mathrm{p}$ (mm) & -0.004 & -0.120 & -0.144 & -0.242 & -0.243 & 0.063 \\
\hline R99p (mm) & -0.131 & -0.224 & -0.231 & -0.277 & -0.104 & -0.022 \\
\hline PRCPTOT (mm) & -0.267 & -0.273 & -0.219 & -0.233 & -0.175 & 0.082 \\
\hline
\end{tabular}


$5 \%$ level. Consistent with the above results, an increase in hot days and maximum temperature agrees with an increase in consecutive dry days as the SST in the Pacific Ocean increases.

Araújo and Brito (2011) investigated the influence of SST in the Pacific and Atlantic Oceans in the precipitation of the states of Bahia and Sergipe using extreme climatic indices. Their results showed positive correlations between the CDD indice and the North Atlantic region, differently from our study, which found positive correlations between the CDD indice and the Niño regions. Their results also showed positive correlations between the RX5day and SDII indices and the South Atlantic region. The CWD and PRCPTOT indices presented negative correlations with the Pacific regions. With these results the authors highlight the influence of SST in the Atlantic and Pacific Oceans on precipitation in the studied region, identifying the role of the ENSO and the Atlantic dipole in the climate behavior of Northeast Brazil.

Costa et al. (2015) studied trends in extreme events of weak and intense precipitation for the semiarid NEB region. Their results indicate that a higher frequency of El Niño events possibly explains the decreasing trend found in precipitation intensity. In general, their results showed an increase in drought intensity and a decrease in intense precipitation events over the years.

Also, from Table 4, it is possible to observe the correlations between the trends of the indices of climatic extremes, depending on the air temperature and precipitation, for the Bebedouro station-PE and the Tropical Atlantic regions. Of the 11 indexes that depend on temperature, 5 have positive and statistical significant $(\mathrm{p}<0.05)$ correlations.

The TR shows a positive correlation with the TSAI region, indicating that an SST increases in this region of the Atlantic Ocean could cause an increase in the number of hot nights. The maximum daily maximum temperature has a positive correlation with the TNAI region, which also implies an increase in the maximum temperature for the Bebedouro-PE station region.

The hot day and night indices, TN90p and TX90p, respectively, show a positive correlation with the TSAI region, indicating an increase in the percentage of hot days and nights when the SST of Atlantic Ocean increases. The DTR is correlated positively with the TNAI region. The rainfall dependent indices did not present statistical significance with the SST regions in the Atlantic Ocean.

Table 5 shows the correlations between the trends of the indices of climatic extremes for the station of Manda-

Table 5 - Correlations between the annual averages of the indices of extremes of air temperature and precipitation and the annual mean Sea Surface Temperature (SST) in the regions of the Equatorial Pacific and the annual mean anomalies of SST Tropical Atlantic Oceans, for the station of Mandacaru-BA, in the period 1966-2014.

\begin{tabular}{|c|c|c|c|c|c|c|}
\hline Indices & Niño $1+2$ & Niño 3 & Niño 3.4 & Niño 4 & TNAI & TSAI \\
\hline SU (Days) & 0.142 & 0.182 & 0.121 & 0.179 & 0.429 & 0.233 \\
\hline TR (Days) & 0.124 & 0.100 & 0.160 & 0.069 & -0.359 & 0.108 \\
\hline $\mathrm{TXx}\left({ }^{\circ} \mathrm{C}\right)$ & 0.081 & 0.187 & 0.172 & 0.310 & 0.401 & 0.290 \\
\hline $\operatorname{TXn}\left({ }^{\circ} \mathrm{C}\right)$ & 0.152 & 0.213 & 0.173 & 0.179 & 0.293 & 0.172 \\
\hline $\mathrm{TNx}\left({ }^{\circ} \mathrm{C}\right)$ & 0.167 & 0.142 & 0.227 & 0.203 & -0.072 & -0.089 \\
\hline $\mathrm{TNn}\left({ }^{\circ} \mathrm{C}\right)$ & 0.061 & 0.049 & 0.130 & 0.047 & -0.370 & -0.079 \\
\hline TX10p (Days) & -0.320 & -0.318 & -0.210 & -0.279 & -0.381 & -0.419 \\
\hline TX90p (Days) & 0.248 & 0.210 & 0.042 & 0.085 & 0.556 & 0.484 \\
\hline TN10p (Days) & -0.067 & -0.081 & -0.161 & -0.072 & 0.408 & -0.067 \\
\hline TN90p (Days) & 0.155 & 0.124 & 0.168 & 0.070 & -0.301 & 0.129 \\
\hline DTR $\left({ }^{\circ} \mathrm{C}\right)$ & 0.227 & 0.216 & 0.070 & 0.126 & 0.546 & 0.172 \\
\hline RX1day (mm) & 0.046 & 0.066 & 0.075 & 0.088 & 0.038 & -0.236 \\
\hline RX5day (mm) & -0.040 & -0.055 & -0.060 & -0.101 & -0.255 & -0.214 \\
\hline SDII (mm) & 0.173 & 0.151 & 0.130 & 0.082 & -0.140 & -0.272 \\
\hline R10mm (Days) & -0.107 & -0.088 & -0.022 & 0.042 & -0.081 & -0.029 \\
\hline R20mm (Days) & -0.042 & -0.029 & 0.041 & 0.062 & -0.142 & -0.080 \\
\hline R30mm (Days) & -0.027 & 0.011 & 0.049 & 0.052 & -0.193 & -0.175 \\
\hline CDD (Days) & 0.364 & 0.389 & 0.376 & 0.305 & 0.292 & -0.121 \\
\hline CWD (Days) & -0.108 & -0.076 & -0.027 & 0.028 & 0.279 & -0.077 \\
\hline R95p (mm) & 0.066 & 0.086 & 0.094 & 0.084 & -0.093 & -0.186 \\
\hline R99p (mm) & 0.143 & 0.171 & 0.156 & 0.142 & 0.047 & -0.261 \\
\hline PRCPTOT (mm) & -0.109 & -0.096 & -0.035 & -0.005 & -0.189 & -0.061 \\
\hline
\end{tabular}


caru-BA and the regions of the Equatorial Pacific Ocean. From the 11 indices, dependent of air temperature, only the TXx presented a positive correlation $(\mathrm{p}<0.01)$ with the Niño 4 region, indicating an increase in the maximum temperature when the SST increases in this region of the Pacific Ocean.

For precipitation dependent indices, as well as for Bebedouro station, only the CDD index presented positive correlations for the four regions of the Pacific Ocean, indicating an increase in consecutive dry days for the area of the Mandacaru-BA station.

Alves (2012) using reanalysis precipitation data showed a decrease in the mean annual precipitation total in NEB. The author suggests that the decline may have been caused by the ENSO and the Atlantic dipole interannual variability. Our results showed an increase in consecutive dry days with statistical significance; however, we cannot affirm that the rise in consecutive dry days results in a decrease in total annual precipitation because although most of the correlations between annual precipitation and SST of the oceans suggest a negative correlation, these are not statistically significant.

Table 5 also shows the correlations between the indices of climatic extremes trends for the station of Mandacaru-BA and the regions of the Equatorial Pacific and Tropical Atlantic Oceans. As for Bebedouro station, only air temperature dependent indices were statistically significant, of these, 6 indices, presented positive and statistically significant correlations $(\mathrm{p}<0.05)$.

The SU index shows a positive correlation with the TNAI region, indicating that when the SST of the North Atlantic Ocean increases it favors the increase in hot days for the Mandacaru station region. The maximum temperature increases when the SST in the TNAI and TSAI regions are warmer. The minimum maximum temperature also shows a positive correlation with the TNAI region.

The TX90p index increases with the increase of SST in the two regions of the Atlantic Ocean, whereas the TN10p increases with the rise of SST in the TNAI region. The DTR shows a positive correlation with the TNAI region, indicating that when the SST of the North Atlantic Ocean is warmer, it favors the increase in the diurnal temperature range for the area of Mandacaru-BA station.

When comparing weak and intense precipitation events in NEB semiarid, Costa et al. (2015) observed that in 1979, a year with weak El Niño performance, a high annual mean of precipitation was verified, which suggests the existence of other factors favoring precipitation. According to the authors, El Niño inhibits precipitation, but as the El Niño of 1979 was weak, they suggest that a positive anomaly of SST in the South Atlantic was able to overcome the inhibition caused by the event, favoring precipitation in the studied region. Therefore, it is verified that the El Niño phenomenon is not always synonymous of drought and that studies on the SST anomalies in the Atlantic Ocean and its influence on NEB precipitation are also necessary. Our results did not present statistical significance for the correlations between climatic extremes indices and the Atlantic Ocean.

The statistically significant correlations between the extremes of temperature and precipitation indices for the two stations and the SSTs in the Pacific Ocean can indicate the influence of El Niño in the study region. This study shows that when the SST of this ocean is warmer could cause an increase in the maximum temperature, hot days, diurnal temperature range and, consequently, an increase in the consecutive dry days.

Besides, the statistically significant correlations between the precipitation extremes indices for the two stations and the SSTs in the Atlantic Ocean do not present significant results $(p<0.05)$ since the Atlantic Ocean does not explain the precipitation in the study region. The active meteorological systems (VCAN and instabilities associated with the cold fronts) responsible for the rainy season in the study region do not depend on the Atlantic Dipole to develop.

\section{Conclusions}

From the results obtained, for the two analyzed stations, it is not possible to affirm that the construction of the Sobradinho Hydroelectric Plant (SHPP) and, the consequent formation of its artificial lake, altered the local microclimate. Since the temporal trends of the extreme precipitation indices presented few values with statistical significance, and the temporal trends of the extreme indices of air temperature presented some contrary results for the two stations studied.

Nevertheless, a trend of increase in maximum temperature, the number of hot days and in the diurnal temperature range, for the two stations studied, was noticed. However, according to the results of Pettitt's statistical test, the increase of these indices cannot be attributed to the formation of the lake of the SHPP.

In addition, the statistically significant correlations between temperature extremes and precipitation indices for the two stations and SST in the Pacific and Atlantic Oceans were positive. Thus, the influence of the SST of these regions on the temporal behavior of some of the indices used in this study may have contributed to increases in hot days and nights, maximum temperature, diurnal temperature range and consecutive dry days.

\section{Acknowledgments}

The authors are grateful to the CAPES for funding the Research Project 88887.091737/2014-01 (Edital CAPES Pró-Alertas 24/2014 under project: “Análise e Previsão dos Fenômenos Hidrometeorológicos Intensos do Leste do Nordeste Brasileiro) and the second author thanks the 
$\mathrm{CNPq}$ for the Research Productivity Grant $\left(\mathrm{CNPq} \mathrm{N}^{\circ}\right.$ 301348/2015-4).

\section{References}

ADDISU, S.; SELASSIE, Y.G.; FISSHA, G.; GEDIF, B. Time series trend analysis of temperature and rainfall in lake Tana Sub-basin, Ethiopia. Environmental Systems Research, v. 4 , p. 25,2015

ALVES, J.M.B. Recentes variações climáticas no Nordeste do Brasil com ênfase a precipitação: relações com o ENOS, dipolo de temperatura da superfície do mar no Atlântico Tropical e a oscilação decadal do Pacífico. Revista de Geografia, v. 29, n. 3, 2012.

ANDREOLI, R.V.; KAYANO, M.T. A importância relativa do Atlântico Tropical Sul e Pacífico Leste na variabilidade de precipitação do Nordeste do Brasil. Revista Brasileira de Meteorologia, v. 22, n. 1, p. 63-74, 2007.

ARAÚJO, W.S.; BRITO, J.I.B. de. Indices of trends of climatic changes for the states of the Bahia and Sergipe by means of daily precipitation indices and its relation with SST's of the Pacific and Atlantic. Revista Brasileira de Meteorologia, v. 26, n. 4, p. 541 - 554, 2011.

BAUER, L. Estimação do coeficiente de correlação de Spearman ponderado. Dissertação de Mestrado. Universidade Federal do Rio Grande do Sul, Porto Alegre, 2007.

BRAZILIAN COMMITTEE OF DAMS. Comitê Brasileiro de Barragens. A história das barragens no Brasil, Séculos XIX, XX e XXI: cinquenta anos do Comitê Brasileiro de Barragens. Rio de Janeiro: CBDB, 2011. Disponível em: http:/www.cbdb.org.br/documentos/A_Historia_das_Barr agens_no_Brasil.pdf. Acesso em: 13 de maio de 2016.

COMPANHIA HIDROELÉTRICA DO SÃO FRANCISCO CHESF. Descrição do aproveitamento de Sobradinho. (https://www.chesf.gov.br/SistemaChesf/Pages/SistemaGe racao/Sobradinho.aspx). Acesso em: Maio, 2016.

CORREIA, M.F.; SILVA DIAS, M.A.F.; SILVA ARAGÃO, M.R. Soil occupation and atmospheric variations over Sobradinho lake area. Part One: An observational analysis. Meteorology and Atmospheric Physics, v. 94, p. 103-113, 2006a.

CORREIA, M.F.; SILVA DIAS, M.A.F.; SILVA ARAGÃO, M.R. Soil occupation and atmospheric variations over Sobradinho lake area. Part Two: A regional modeling study. Meteorology and Atmospheric Physics, v. 94, p. 115-128, 2006b.

COSTA, M. da S.; LIMA, K.C.; ANDRADE, M. de M.; GONÇALVES, W.A. Tendências observadas em extremos de precipitação sobre a região Semiárida do Nordeste do Brasil. Revista Brasileira de Geografia Física, v. 8 n. 5, p. 13211334, 2015.

FISCH, G.F.; JANUÁRIO, M., SENNA, R.C. Impacto ecológico em Tucuruí (PA): climatologia. Acta Amazônica, v. 20, n. 1, p. 49-60, 1990.

GOOSSENS, C.; BERGER, A. Annual and seasonal climatic variations over the northern hemisphere and Europe during the last century. Annales Geophysical, v. 4, p. 385-400, 1986.

HAYLOCK, M.R.; PETERSON, T.C.; ALVES, L.M.; AMBRIZZI, T.; ANUNCIAÇÃO, Y.M.T.; BAEZ, J.; BARROS, V.R.; BERLATO, M.A.; BIDEGAIN, M.; CORONEL, G.;
GARCIA, V.J.; GRIMM, A.M.; KAROLY, D.; MARENGO, J.A.; MARINO, M.B.; MONCUNILL, D.F.; NECHET, D.; QUINTANA, J.; REBELLO, E.; RUSTICUCCI, M.; SANTOS, J.L.; TREBEJO, I.; VINCENT, L.A. Trends in total and extreme South American rainfall 1960-2000 and links with sea surface temperature. Journal of Climate, v. 19, p. 1490-1512, 2006.

HUANG, J.; SUN, S.; XUE, Y.; ZHANG, J. Spatial and temporal variability of precipitation indices during 1961-2010 in Hunan Province, central south China. Theoretical and Applied Climatology, v. 118, p. 581-595, 2014.

IPCC - Intergovernmental Panel in Climate Change. Climate Change 2013 - The Physical Science Basis. Working Group I Contribution to the IPCC Fifth Assessment Report. Summary for Policymakers. IPCC, Stockholm, Sweden. 2013.

IPCC - Intergovernmental Panel in Climate Change. Managing the Risks of Extreme Events and Disasters to Advance Climate Change Adaptation. Special Report of Working Group I and II of the Intergovernmental Panel on Climate Change. Edited by C. B. Field et al. Cambridge/New York, Cambridge University Press/IPCC, 2012.

IPCC [Core Writing Team, R.K. Pachauri and L.A. Meyer (eds.)]. Climate Change 2014: Synthesis Report. Contribution of Working Groups I, II and III to the Fifth Assessment Report of the Intergovernmental Panel on Climate Change. IPCC, Geneva, Switzerland: (2014): 151. http://www.ipcc.ch/pdf/assessment-report/ar5/syr/SYR_AR5_FINAL_full.pdf.

JOHNSTON, R.M.; KUMMU, M. Water resource models in the Mekong Basin: a review. Water Resources Management, v. 26, p. 429-455, 2012.

KAYANO, M.T; CAPISTRANO, V.B.; ANDREOLI, R.V.; SOUZA, R.A.F.A further analysis of the tropical Atlantic SST modes and their relations to north-eastern Brazil rainfall during different phases of Atlantic Multidecadal Oscillation. International Journal of Climatology, v. 36, p. 4006-4018, 2016.

KESKINEN, M.; KUMMU, M.; KAKONEN, M.; VARIS, O. Mekong at the Crossroads: Next Steps for Impact Assessment of Large Dams. Ambio, v. 41, p. 319-324, 2012.

KLEIN TANK, A.M.G; ZWIERS, F.W., ZHANG, X. Guidelines on analysis of extremes in a changing climate in support of informed decisions for adaptation. World Meteorological Organization, p. 55, 2009.

LIMA, J.R.A.; NEVES, D.J.D.; AZEVEDO, P.V. Identificação de tendências climáticas no estado da Bahia. Revista de Geografia, v. 28, n. 3, 2011.

NANDINTSETSEG, B.; GREENE, J.S.; GOULDEN, C.E. Trends in extreme daily precipitation and temperature near Lake Hovsgol, Mongolia. International Journal of Climatology, v. 27, p. 341-347, 2007.

PBMC - Painel Brasileiro de Mudanças Climáticas. Base Científica das Mudanças Climáticas. Contribuição do Grupo de Trabalho 1 do Painel Brasileiro de Mudanças Climáticas ao Primeiro Relatório de Avaliação Nacional sobre Mudanças Climáticas. Organização de T. Ambrizzi \& M. Araujo. Rio de Janeiro, Coppe/Universidade Federal do Rio de Janeiro, 2014.

PEREIRA, S.B; PRUSKI, F.F.; SILVA, D.D. da; RAMOS, M.M. Evaporação líquida no lago de Sobradinho e impactos no 
escoamento devido à construção do reservatório. Revista Brasileira de Engenharia Agrícola e Ambiental, v. 13, n. 3, p. 346-352, 2009.

PETTITT, A.N.A non-parametric approach to the change-point problem. Applied Statistics, v. 28, p. 126-135, 1979.

PHILIP, A.; AUGISTINE, Y.; ABINDAW, B. Impact of climate variability on smallholder households and indigenous coping strategies in Bonga district. International Journal of Development Research, v. 4, p. 693-699, 2014.

RODRIGUES, R.R.; HAARSMA, R.J.; CAMPOS, E.J.D.; AMBRIZZI, T. The Impacts of Inter-El Niño Variability on the Tropical Atlantic and Northeast Brazil Climate. Journal of Climate, v. 24, p. 3402-3422, 2011.

SANCHES, F.; FISCH, G. As possíveis alterações microclimáticas devido à formação do lago artificial da hidrelétrica de Tucuruí - PA. Acta Amazônica, v. 35, n. 1, p. 41-50, 2005.

SANTOS, J.F.; PORTELA, M.M. Quantificação de tendências em séries de precipitação mensal e anual em Portugal Continental, VIII Seminário Ibero Americano sobre Sistemas de Abastecimento Urbano, SEREA 2008, IST, Lisbon, Portugal.

SEN, P.K. "Estimates of the regression coefficient based on Kendall's Tau", Journal of the American Statistical Association, v. 63, p. 1379-1389, 1968.

SILVA, G.B., AZEVEDO, P.V. de. Índices de tendências de mudanças climáticas no estado da Bahia. Engenharia Ambiental, Espírito Santo do Pinhal, v. 5, n. 3, p. 141-151, 2008.

SILVA, M.T.; SILVA, V.P.R.; SOUZA, E.P. Morphometric analysis of the basin low middle São Francisco river. Journal of Hyperspectral, Remote Sensing, v. 4, n. 8, p. 168-174, 2014.

SILVA, M.T.; SILVA, V.P.R; SOUZA, E.P.; ARAÚJO, A.L. SWAT model application to estimate the flow in the basin of lower-middle São Francisco River. Revista Brasileira de Geografia Física, v. 8, p. 1615-1627, 2015.

SILVA, V.P.R.; SILVA, M.T.; SOUZA, E.P. Influence of land use change on sediment yield: a case study of the sub-middle of the São Francisco River basin. Engenharia Agrícola, v. 36, n. 6, p. 1005-1015, 2016.

SNEYERS, R. On the Statistical Analysis of Series of Observations. Technical Note No. 143, WMO No. 415 World Meteorological Organization: Geneva, 1990.

SNEYERS, R. Sur lanalyse statistique des séries dobservations. Genève: Organisation Météorologique Mondial, 192p. (OMM Note Technique, 143), 1975.

UVO, C.B.; REPELLI, C.A.; ZEBIAK, S.E.; KUSHNIR, Y. The Relationships between Tropical Pacific and Atlantic SST and Northeast Brazil Monthly Precipitation. Journal of Climate, v. 11, p. 551-562, 1998.

WANG, X.L.; YANG, F. RHtestsV3 user manual. 2010. http://cccma.seos.uvic.ca/ETCCDI/software.shtml.

WATSON, R.T, IPCC Core Writing Team (eds). Climate Change 2001, Synthesis Report. A Contribution of Working Groups I, II, and III to the Third Assessment Report of the Intergovernmental Panel on Climate Change. Cambridge University Press, Cambridge, 2001.

ZHANG, X.; AGUILAR, E.; SENSOY, S.; MELKNYAN, H.; TAGHIYEVA, U.; AHMED, N.; KUTALADZE, N.; RAHIMZADEH, F.; TAGHIPOUR, A.; HANTOSH, T.H.; ALBERT, P.; SEMAWI, M.; ALI, M.K.; HALAL, M.; ALSHABIBI, A.; AL-OULAN, A.; ZATARI, A.; AL DEAN KHALIL, I.; SAGIR, R.; DEMIRCAN, M.; EKEN, M.; ADIGUZEL, M.; ALEXANDER L; PETERSON, T.C.; WALLIS, T.; Trends in Middle East climate extremes indices during 1930-2003. Journal of Geophysical Research-Atmospheres, v. 110, D22104, 2005a.

ZHANG, X.; HEGERL, G.; ZWIERS, F.W.; KENYON, J.; Avoiding inhomogeneity in percentile-based indices of temperature extremes. Journal of Climate, v. 18, p. 1641-1651, $2005 b$.

ZHANG, X.; YANG, F.; RClinDex (1.0) User Guide. Climate Research Branch Environment Canada: Downsview, Ontario, Canada, 2004.

\section{Internet Resources}

CLIMATE PREDICTION CENTER - NATIONAL OCEANIC AND ATMOSPHERIC ADMINISTRATION (CPC NOAA) Available in http://www.esrl.noaa.gov/psd/data/climateindices/list/.

ETCCDI CLIMATE CHANGE INDICES. Available in http://etccdi.pacificclimate.org/software.shtml.

MET OFICCE. Available in https://www.metoffice.gov.uk/research/climate/seasonal-to-decadal/gpc-outlooks/atlantic-indian-ocean.

NATIONAL CLIMATIC DATA CENTER - NATIONAL OCEANIC AND ATMOSFERIC ADMINISTRATION (NCDC - NOAA). Available in https:/www.ncdc.noaa.gov/teleconnections/enso/indicators/sst.php.

THE R PROJECT FOR STATISTICAL COMPUTING. Available in https://www.r-project.org/.

This is an Open Access article distributed under the terms of the Creative Commons Attribution Non-Commercial License which permits unrestricted non-commercial use, distribution, and reproduction in any medium provided the original work is properly cited. 